\title{
IDENTIFIKASI POTENSI TINGGALAN ARKEOLOGI KLASIK DI KECAMATAN SAROLANGUN, JAMBI: PENDEKATAN PREDICTIVE MODELLING
}

\section{THE IDENTIFICATION OF POTENTIAL CLASSICAL ARCHAEOLOGICAL REMAINS IN SAROLANGUN, JAMBI: A PREDICTIVE MODELLING APPROACH}

\author{
Nainunis Aulia Izza, Ari Mukti Wardoyo Adi, dan Nugrahadi Mahanani \\ Program Studi Arkeologi, Universitas Jambi. Kampus UNJA Mendalo, Jalan Jambi-Muara Bulian Km.15, Kabupaten Muaro Jambi, \\ Indonesia; posel; nainunis@unja.ac.id, ariwardoyo@unja.ac.id., dan nmahanani@unja.ac.id
}

\begin{abstract}
Abstrak. Penelitian ini dilakukan atas dasar hipotesis tentang keberadaan tinggalan-tinggalan masa klasik yang berada di Daerah Aliran Sungai Batanghari. Kecamatan Sarolangun dipilih karena hingga kini belum pernah diteliti potensinya tentang tinggalan pemukiman arkeologi klasik. Tinggalan arkeologi klasik yang pernah dilaporkan hanyalah arca Ganesha yang saat ini disimpan di Museum Sultan Mahmud Badaruddin II, Palembang. Penelitian ini dilakukan dengan metode predictive modelling dengan menggunakan perangkat Sistem Informasi Geografis untuk dapat membantu memperkirakan titik-titik yang mengandung potensi tinggalan arkeologi. Variabel prediksi yang digunakan adalah laporan temuan, model lokasi situs, informasi masyarakat, serta potensi temuan permukaan. Hasil penelitian menunjukkan bahwa terdapat beberapa lokasi di Kecamatan Sarolangun yang memiliki sensitivitas tinggi terhadap tinggalan arkeologi klasik. Sensitivitas tinggalan arkeologi ini kemudian diturunkan dalam bentuk peta potensi. Tujuan utama dari pembuatan peta tersebut adalah agar dapat menentukan strategi riset lanjutan.
\end{abstract}

Kata kunci: Tinggalan arkeologi klasik, Daerah Aliran Sungai Batanghari, Sarolangun, Predictive modelling, Sistem informasi geografis

\begin{abstract}
This research was conducted on the basis of a hypothesis about the existence of the remains of the classical period in the Batanghari River Basin. Sarolangun District was chosen because until today there has not been any investigation on classical archaeological settlements. The only classical archeological remains that have been reported are the Ganesha statue which is currently stored in the Sultan Mahmud Badaruddin II Museum, in Palembang. This research was conducted using a predictive modelling method by employing a Geographic Information System to be able to help estimate points containing potential archaeological remains. Predictive variables used are report findings, site location models, community information, and potential surface findings. The results showed that there are several locations in Sarolangun District that have high sensitivity to classical archeological remains. The sensitivity of the archaeological remains is then derived in the form of a potential map. The main purpose of making the map is to be able to determine further research strategies.
\end{abstract}

Keywords: Classical archaeological remains, Batanghari river catchment, Sarolangun, Predictive modelling, Geographic information system

\section{PENDAHULUAN}

Tinggalan arkeologi klasik di Pulau Sumatra pada umumnya ditemukan di sepanjang aliran sungai utama yang merupakan bagian dari Daerah Aliran Sungai (DAS), misalnya Sungai Lematang, Sungai Batanghari Leko, dan Sungai Musi di DAS Musi; Sungai Batanghari di DAS Batanghari; Sungai Kampar di DAS Kampar; Sungai Pane, dan Sungai Barumun di DAS Barumun. Penelitian pada masa Hindia-Belanda di DAS Batanghari, yang mayoritas berada di wilayah administratif Provinsi Jambi saat ini, menemukan berbagai situs arkeologi klasik (Schnitger 1937; Tideman 1938). Jumlah temuan situs dan tinggalan arkeologi klasik tersebut terus bertambah seiring penelitian lebih lanjut yang dilakukan oleh Dinas Purbakala pada periode pascakemerdekaan.

Wilayah yang memiliki kepadatan tinggalan arkeologi klasik tertinggi di DAS Batanghari adalah kawasan percandian Muarajambi. Di Muarajambi ditemukan berbagai tinggalan masa klasik yang umumnya berlatar agama Buddha. Hal ini seiring dengan adanya interpretasi bahwa pada masa lalu Muarajambi adalah pusat pendidikan agama Buddha yang disebutkan dalam kronik Cina (Groeneveldt 2018). Selain temuan berlatar agama Buddha, juga ditemukan satu arca wahana berlatar agama Hindu berupa Nandi (Neeb 1902; Schnitger 
1937; Tim Penelitian Arkeologi Muara Jambi 1986). Selain di Muarajambi, tinggalan arkeologi klasik yang diduga berlatar agama Hindu di DAS Batanghari, antara lain berada di Timpeh, Sarolangun, dan Koto Kandis. Arca Ganesha pernah ditemukan di Desa Timpeh, Kecamatan Sitiung, Kabupaten Dharmasaraya, dan sekarang disimpan di Pusat Penelitian Arkeologi Nasional. Arca Ganesha setengah jadi juga pernah ditemukan di Kampung Lubuk, Kecamatan Sarolangun, Kabupaten Sarolangun, tepatnya di tepian Sungai Batang Asai, anak dari Sungai Batanghari. Temuan ini sekarang menjadi koleksi Museum Sultan Mahmud Badaruddin II. Selain kedua arca tersebut, terdapat juga arca Dipalaksmi yang sekarang menjadi koleksi Museum Siginjei ditemukan di Situs Koto Kandis, Kabupaten Tanjung Jabung Timur (Adam 1921, 1922; Tideman 1938; Utomo 2016).

Jumlah tinggalan arkeologi berlatar agama Hindu di DAS Batanghari memang tidak sebanyak yang ditemukan di DAS lain. Terlebih apabila dibandingkan dengan jumlah seperti di Percandian Bumiayu, di Sumatra Selatan dan Candi Simangambat di Sumatra Utara (Schnitger 1937; Taim 2010). Demikian juga dengan jenis dan karakter tinggalannya. Temuan berlatar agama Hindu di DAS Batanghari yang diketahui sampai saat ini hanya berupa arca. Tinggalan monumental berupa candi atau situs yang menunjukkan napas keagamaan Hindu belum pernah ditemukan. Terkait dengan arca Ganesha dari Kecamatan Sarolangun, belum didapatkan informasi lebih lanjut, kecuali patut diduga kuat bahwa arca tersebut memang berasal (dibuat) di tempat tersebut. Hal ini berdasarkan pada kondisi arca yang dibuat dari batu dengan ukuran relatif besar dan keadaannya yang masih setengah jadi (Utomo 2016).

Berdasarkan laporan yang ditulis oleh T. Adam (1922), selain arca Ganesha, pernah ditemukan arca lain yang dilengkapi dengan angka tahun (Adam 1922). Akan tetapi, arca tersebut kini tidak dapat dijumpai lagi. Temuan lain di Sarolangun yang diduga merupakan tinggalan masa klasik menurut Tideman (1938) adalah struktur bata yang menjadi fondasi suatu musala (Tideman 1938). Sampai sekarang belum ada penelitian lebih lanjut mengenai situs-situs di Kecamatan Sarolangun, bahkan menurut laporan terbaru tentang registrasi kepurbakalaan di Kabupaten Sarolangun, kepurbakalaan yang dideskripsikan hanya berasal dari masa prasejarah dan kolonial.

Berdasarkan uraian di atas, temuan arca Ganesha, menurut latar agamanya, merupakan tinggalan arkeologi klasik yang relatif langka di DAS Batanghari. Temuan lain, seperti struktur bata dan laporan tentang arca berangka tahun yang telah hilang, juga menguatkan indikasi keberadaan situs-situs dari masa klasik yang ada di Kecamatan Sarolangun. Untuk itu, penelusuran potensi tinggalan masa klasik di Kecamatan Sarolangun sangat dibutuhkan. Studi tersebut diharapkan akan menghasilkan pemetaan tentang potensi situs klasik di Kecamatan Sarolangun. Di samping itu, pemetaan potensi ini diharapkan akan turut menambah informasi mengenai tinggalan berlatar kebudayaan Hindu-Buddha di DAS Batanghari.

Aktivitas dan perilaku manusia dalam memanfaatkan wilayah di sekitar tempat tinggalnya untuk memenuhi kebutuhan hidup pasti memiliki pola-pola tertentu. Premis dasar ini sering digunakan sebagai alasan pokok dalam penelitian arkeologi modern (Brandt, Groenewoudt, dan Kvamme 1992). Model lokasional situs arkeologi yang telah banyak dihasilkan dari berbagai penelitian menunjukkan pola-pola tersebut dipengaruhi oleh faktor bentang lahan seperti topografi, jenis tanah, ataupun akses terhadap air (Parker 1985). Beberapa penelitian mengenai pola persebaran tinggalan arkeologi telah membuktikan bahwa masyarakat masa lalu memiliki pertimbangan dalam memilih lokasi untuk mendirikan pemukiman (Adi 2012; Degroot 2009; Mundarjito 1993; Nugroho 2000; Soeroso 1996). Komponen permukiman berupa bangunan suci masa klasik, bahkan memiliki pola-pola tersendiri yang unik. Dalam kitab-kitab pedoman pendirian bangunan suci di India, seperti Manasara-Silpasastra dan Silpaprakarsa menyebutkan bahwa bangunan suci harus didirikan pada lokasi-lokasi tertentu sesuai dengan peruntukannya (Mundarjito 1993). Dengan asumsi dasar mengenai pemilihan lokasi pendirian bangunan suci ini, dapat diperkirakan tinggalan-tinggalan arkeologi klasik akan ditemukan pada bentang lahan dengan karakteristik tertentu yang memiliki keunikan.

Berkaitan dengan tinggalan masa klasik di Kecamatan Sarolangun, terdapat permasalahan terkait dengan belum adanya penelusuran dan pemetaan potensi terkini. Penelusuran potensi arkeologi dapat dilakukan dengan mengaplikasikan metode predictive modelling. Untuk itu, permasalahan yang diajukan dalam penelitian ini adalah seberapa besar tingkat sensitivitas tinggalan dari masa klasik di Kecamatan Sarolangun.

Penelitian ini merupakan tahap awal penelusuran tinggalan masa klasik di Kecamatan Sarolangun, baik yang sudah pernah tercantum pada laporan-laporan Belanda maupun kemungkinan keberadaan situs yang belum pernah didata sama sekali. Penelitian penting dilakukan sebagai upaya mengungkap peradaban nenek 
moyang pada masa Hindu-Buddha di DAS Batanghari sekaligus upaya melindungi dan melestarikan tinggalan materialnya. Selain itu, hasil penelitian diharapkan dapat menjadi pengetahuan baru bagi masyarakat sekitar serta bahan masukan bagi pemerintah Kecamatan dan Kabupaten Sarolangun untuk melestarikan dan melakukan studi lanjutan berkaitan dengan tinggalan arkeologi di daerahnya.

\section{METODE}

Metode predictive modelling termasuk metode yang baru dalam kajian arkeologi di Indonesia. Metode ini menggunakan perangkat Sistem Informasi Geografis (SIG) sebagai alat utama untuk membangun kerangka pikir dan model, memproses data, menganalisis, dan merepresentasikan model yang dibuat berdasarkan interpretasi. Metode predictive modelling dinilai mempunyai efektivitas tinggi dalam operasionalnya, termasuk biaya dan waktu, apabila dikomparasikan dengan metode arkeologi konvensional (Kvamme 1983, 1990; Verhagen 2007). Sebagian besar kajian yang menggunakan metode predictive modelling dilakukan menggunakan komputer, sedangkan metode konvensional, seperti survei terestrial dan ekskavasi, dilakukan di lapangan yang membutuhkan biaya lebih mahal serta waktu lama.

Predictive modelling merupakan suatu metode untuk memperkirakan kemungkinan keberadaan dari variabel terikat dalam suatu wilayah yang belum pernah tersampel menggunakan variabel bebas. Aplikasinya dalam bidang ilmu arkeologi cenderung diasosiasikan dengan percobaan untuk menilai kemungkinan keberadaan situs arkeologi dalam suatu wilayah yang belum pernah ditemukan situs arkeologinya. Penilaian ini dilakukan dengan cara kuantitatif pada karakteristik bentang lahan suatu situs arkeologi yang pernah ditemukan (Conolly dan Lake 2006; Ebert dan Kobler 1988; Kvamme 1983; 1990; Wescott dan Brandon 2000).

Conolly dan Lake (2006) juga menjelaskan bahwa penerapan predictive modelling dalam arkeologi dapat memberikan dukungan informasi yang sangat diperlukan pada bidang Cultural Resource Management (CRM). Metode predictive modelling dianggap memiliki kekuatan dalam memprediksi keberadaan tinggalan arkeologi di wilayah yang belum pernah diteliti secara arkeologis (Kvamme 1983; 1990). Permasalahan utama dalam metode predictive modelling bukanlah pada kontribusinya terhadap eksplanasi mengenai lokasi situs, tetapi lebih tepatnya terkait akurasi dan presisinya (Conolly dan Lake 2006). Hal ini perlu dipahami mengingat banyak peneliti arkeologi sejauh ini selalu mempermasalahkan eksplanasi terhadap lokasi sebuah situs tanpa melihat metode yang digunakan dalam penelitian tersebut (Conolly dan Lake 2006; Verhagen 2007).

Predictive modelling dalam penelitian ini digunakan untuk memprediksi secara lebih jauh keberadaan tinggalan klasik di Kecamatan Sarolangun. Tinggalan yang dimaksud adalah sisa-sisa aktivitas manusia pada masa lalu, baik berupa ruang hunian, ruang peribadatan, maupun ruang subsistensi. Cara yang dilakukan adalah dengan menelaah kemungkinan penempatan situs-situs klasik berdasarkan faktor bentang lahan serta bentang budayanya.

Terdapat empat variabel dalam penelitian ini yang bersifat kualitatif (Tabel 1) (Adi 2016; Yuwono 2015). Variabel pertama yang digunakan dalam penelitian ini adalah laporan. Laporan yang dimaksud adalah keberadaan laporan tinggalan arkeologi, baik dari pemerintah kolonial Belanda maupun dari masyarakat setempat. Variabel kedua adalah karakteristik lanskap. Variabel ini diambil karena situs-situs arkeologi dari periode klasik seringkali menempati wilayah dengan karakteristik lanskap yang unik, seperti pertemuan sungai (muara), bekas aliran sungai kuno yang telah menjadi oxbow lake, serta tanggul-tanggul alam yang berdekatan dengan rawa belakang. Variabel yang ketiga adalah toponimi. Toponimi merupakan variabel mengenai keberadaan nama-nama lokasi yang memiliki kedekatan istilah dengan tinggalan arkeologi klasik, seperti koto, biaro, candi, bata, dan toponim sejenis. Pada umumnya nama lokasi selalu berkaitan dengan sumber daya ataupun keberadaan fenomena yang ada di tempat tersebut (Mashadi dan Zuharnen 2014; Munandar 2016). Toponim tersebut dapat dijumpai pada peta-peta yang ada pada saat ini ataupun peta terbitan pemerintah Hindia-Belanda. Variabel terakhir adalah keberadaan tinggalan arkeologi yang masih ditemukan sampai saat ini, seperti runtuhan bangunan, fragmen-fragmen keramik kuno, dan sejenisnya.

Keempat variabel tersebut memiliki bobot yang penilaiannya ditentukan secara biner oleh peneliti. Hal ini karena hingga sekarang belum pernah ada formula penentuan bobot dan harkat dalam kajian predictive modelling arkeologi yang dilakukan di Indonesia. Penentuan keempat variabel dalam penelitian ini akan dilakukan di seluruh Kecamatan Sarolangun, baik pada titik-titik yang sebelumnya pernah dilaporkan memiliki 
tinggalan arkeologi klasik maupun pada titik-titik yang belum pernah dilaporkan, tetapi terindikasi memiliki tinggalan arkeologi klasik berdasarkan variabelnya. Selanjutnya, titik-titik tersebut akan didata dan menjadi areaarea sensitif. Area-area sensitif dalam penelitian ini dinilai menggunakan metode validasi lapangan.

Tabel 1 Variabel Sensitivitas Lokasi

\begin{tabular}{clcc}
\hline No & Variabel & Tidak Ada & Ada \\
\hline 1 & Laporan & 0 & 1 \\
\hline 2 & Karakteristik Lanskap & 0 & 1 \\
\hline 3 & Toponim & 0 & 1 \\
\hline 4 & Temuan di Lapangan & 0 & 1
\end{tabular}

Sumber: Hasil Penelitian 2019

Area-area sensitif dalam penelitian ini dinilai menggunakan empat tahapan metode, yaitu grid, sentroid, interpolasi, dan validasi di lapangan (Adi 2016; Gibbon 2007; Krivoruchko, Gribov, dan Krause 2011; Kvamme 1997; Robinson dan Zubrow 1999; Yuwono 2015). Metode grid dilakukan paling awal karena dianggap mempunyai efektivitas paling tinggi dalam menentukan tingkat sensitivitas sebuah lokasi. Metode ini hampir sama dengan analisis raster dalam pengindraan jauh. Grid memiliki luasan yang seragam sehingga dapat digunakan sebagai unit analisis dasar untuk mengkalkulasi kepadatan populasi tinggalan arkeologi berdasarkan atributnya (Kvamme 1997). Nilai sensitivitas suatu grid dinilai dari keberadaan kriteria yang ditentukan sebagai variabel sensitivitas lokasi. Setiap grid di wilayah penelitian merepresentasikan area dengan luasan $100 \mathrm{~m} \mathrm{x}$ 100 m. Luasan ini didasarkan pada pendapat Guy Gibbon (2007) mengenai model resolusi spasial untuk analisis predictive modelling. Penentuan tingkat sensitivitas tinggalan arkeologi dalam suatu area harus menggunakan luasan grid yang rasional. Luasan tersebut antara $<0,04 \mathrm{~km}^{2}$ hingga $>1,01 \mathrm{~km} 2$. Luasan di bawah 0,04 km² memiliki probabilitas tinggi tetapi akurasi rendah, sedangkan luasan di atas $1,01 \mathrm{~km}^{2}$ memiliki probabilitas rendah tetapi akurasi tinggi. Hal ini berarti makin luas suatu grid sebagai unit analisis, probabilitas akan adanya tinggalan arkeologi makin tinggi, tetapi presisi dari modelnya akan rendah. Sebaliknya, makin sempit luas suatu grid, probabilitas akan makin rendah, tetapi presisinya makin tinggi (Gibbon 2007). Luasan grid yang ditentukan dalam penelitian ini merupakan luasan yang paling ideal, karena dapat mewakili probabilitas dan akurasi yang paling memadai untuk wilayah Kecamatan Sarolangun. Menurut data dari Badan Pusat Statistik (2019), luas Kecamatan Sarolangun adalah 498.000 hektar. Pada tahap ini Kecamatan Sarolangun akan dibagi menjadi grid dengan ukuran $100 \mathrm{~m}$ x $100 \mathrm{~m}$ dan selanjutnya akan diproses dengan metode sentroid.

Metode sentroid merupakan tahap selanjutnya yang digunakan untuk mengubah tiap-tiap grid menjadi titik pusat grid. Titik ini memiliki nilai atribut yang sama dengan grid dan akan digunakan untuk tahapan selanjutnya, yaitu interpolasi. Interpolasi merupakan metode untuk memperkirakan nilai pada suatu lokasi yang bukan merupakan lokasi sampel, berdasarkan nilai yang terdapat pada lokasi-lokasi di sekitarnya yang digunakan sebagai sampel (Borrough dan McDonnell 1998). Interpolasi juga dapat diartikan sebagai suatu cara atau fungsi matematis untuk memperkirakan nilai pada lokasi-lokasi yang datanya kosong (Hadi 2013). Dalam arkeologi predictive modelling, tahap interpolasi dilakukan untuk reagregasi nilai lokasi yang tidak ada tinggalan arkeologi agar dapat diketahui tingkat sensitivitas atau pengaruh kekuatan variabel yang mempengaruhi keberadaan tinggalan arkeologi (Krivoruchko dkk. 2011). Tahap ini mengubah data titik sentroid menjadi raster yang dapat diklasifikasi berdasarkan nilai yang terkalkulasi secara otomatis melalui operasi komputer. Interpolasi akan memberikan bantuan untuk melakukan pendugaan potensi tinggalan arkeologi pada suatu wilayah berdasarkan variabel yang ada di sekitarnya (Robinson dan Zubrow 1999). Hasil dari interpolasi merupakan peta sensitivitas tinggalan arkeologi yang perlu diuji keakuratan dan presisinya di lapangan. Oleh karena itu, tahap terakhir dalam penelitian ini akan dilakukan dengan validasi di wilayah penelitian. Validasi dimaksudkan untuk melihat, jika berdasarkan model yang dibuat, apakah dapat digunakan untuk menemukan tinggalan arkeologi. 


\section{HASIL DAN PEMBAHASAN}

\section{Tinggalan Arkeologi Klasik di Jambi}

Masa klasik di Indonesia yang identik dengan masa perkembangan kerajaan Hindu-Buddha terjadi pada kurun waktu abad ke-4--16 Masehi (M). Tinggalan dari masa klasik yang banyak ditemukan di Indonesia, antara lain berupa bangunan candi dan arca (Hardiati dkk. 2010). Pembahasan mengenai masa klasik di Sumatra, terutama di DAS Batanghari tidak dapat dilepaskan dari keberadaan Kerajaan Sriwijaya serta Melayu Kuno (Coedes 2010).

Penelitian tentang masa klasik di Sumatra telah dilaksanakan sejak masa pemerintah kolonial Belanda. Berdasarkan laporan-laporan Belanda, tinggalan masa klasik di Sumatra dapat ditemukan dari ujung utara sampai selatan pulau ini (Schnitger 1937). Tinggalan-tinggalan tersebut pada umumnya mengelompok pada suatu wilayah yang patut diduga merupakan pusat aktivitas manusia pada masa lampau. Tinggalan-tinggalan masa klasik yang membentuk kelompok terluas terletak di Muarajambi. Kawasan percandian Muarajambi dalam laporan Belanda pertama kali dibahas oleh S.C. Crooke (Esquire 1826). Selanjutnya, Schnitger (1937) juga menerbitkan buku berjudul The Archaeology of Hindoo Sumatra yang berisi uraian deskriptif tentang tinggalan klasik yang dibagi berdasarkan kawasan temuannya (Schnitger 1937). Hal ini menunjukkan bahwa pada masa lalu, Sumatra pada umumnya serta DAS Batanghari pada khususnya, telah menjadi lokasi perkembangan peradaban yang sisa-sisanya masih dapat ditelusuri sampai hari ini

Pada masa Belanda, penyebutan tinggalan klasik umumnya memakai kata Hindoo yang identik dengan Agama Hindu. Jadi baik tinggalan yang bernapaskan Hindu, Buddha, maupun tinggalan profan dari masa klasik disebut sebagai tinggalan Hindoo. Dalam sejumlah laporann, beberapa arca megalitik di Pasemah juga dikategorikan sebagai Hindoo oudheden (Tombrink 1870; Ullmann 1850; Westenenk 1922). Menurut kronologinya, tinggalan klasik di Jambi berasal dari abad ke-7 M sampai dengan abad ke-14 M (Hardiati dkk. 2010). Menurut lokasinya, tinggalan arkeologi klasik di Provinsi Jambi tersebar hampir di seluruh kabupaten.

Tinggalan klasik yang ditemukan di Jambi umumnya diidentifikasi sebagai bangunan sakral (keagamaan). Padahal tinggalan bangunan keagamaan tidak akan pernah lepas dari pemukiman dan hunian masyarakat pendukungnya. Keberadaan suatu bangunan sakral akan menjadi indikator bagi keberadaan permukiman (Ahimsa-Putra 1995).

\section{Potensi Tinggalan Arkeologi Klasik di Kecamatan Sarolangun}

Cakupan wilayah penelitian ini adalah Kecamatan Sarolangun, Kabupaten Sarolangun, Provinsi Jambi (Gambar 1). Batas administratif ini dipilih karena adanya beberapa laporan Belanda yang menyebutkan tinggalan klasik di wilayah tersebut. Selain itu, informasi dari beberapa anggota masyarakat mengatakan bahwa di sekitar Kampung Lubuk terdapat bekas bangunan candi yang saat ini lokasinya digunakan masyarakat sebagai tempat berdirinya langgar atau mushola. Lokasi lain yang dilaporkan berada di lahan makam yang disebut sebagai Makam Muara Sawah. Laporan pemerintah kolonial Belanda hanya menyebutkan adanya suatu runtuhan bangunan candi yang saat ini berada di bawah suatu surau (Tideman 1938).

Berdasarkan karakteristik lanskapnya, beberapa lokasi di Kecamatan Sarolangun dapat diduga memiliki sensitivitas lokasi. Umumnya, wilayah-wilayah yang berada di pertemuan dua sungai, atau sering disebut muara, di Sumatra memiliki potensi kandungan tinggalan arkeologi klasik. Sebagai contoh, pertemuan Sungai Barumun dan Sungai Pannai menjadi lokasi Kompleks Percandian Padang Lawas, pertemuan Sungai Kampar Kanan dan Sungai Kampar Kiri menjadi lokasi Kompleks Percandian Muara Takus, pertemuan Sungai Batanghari dan Sungai Jambi menjadi lokasi Kompleks Percandian Muarajambi, pertemuan sungai Batanghari Leko dan Sungai Musi menjadi lokasi situs Teluk Kijing.

Teori yang dikemukakan oleh Bennet Bronson (1977) mengenai pertemuan sungai sebagai tempat pertukaran barang dan jasa tampaknya dapat diterapkan di sungai-sungai utama di Sumatra. Wilayah-wilayah pertemuan sungai ini selalu mengandung tinggalan arkeologi, dan berkembang menjadi kota-kota besar saat ini (Bronson 1977). Selain pertemuan sungai, tampaknya bekas-bekas aliran sungai yang saat ini menjadi danau tapal kuda, dan di tepiannya masih tumbuh permukiman, juga diduga mengandung tinggalan arkeologi klasik. 
Salah satu contoh di antaranya adalah Danau Sipin. Pada tepian danau tapal kuda ini dijumpai beberapa situs periode klasik seperti Candi Solok Sipin, Candi Sekarabah, Candi Kotoh, dan Candi Sausekip. Oleh karena itu, patut diduga bahwa pemukiman yang polanya masih mengikuti aliran danau tapal kuda sudah berkembang sejak periode klasik.

Beberapa toponim yang dijumpai di Kecamatan Sarolangun juga memiliki indikasi keberadaan situs klasik. Salah satunya adalah Danau Biaro. Danau Biaro merupakan danau tapal kuda yang masih terdapat permukiman yang berlokasi mengikuti alirannya. Biaro sendiri juga diduga kuat memiliki keterkaitan dengan penyebutan tempat peribadatan dari periode klasik (Gambar 2). Biaro merupakan penyebutan lain untuk candi atau bangunan peribadatan yang berlatar agama Hindu Buddha.

Hasil dari analisis variabel menunjukkan bahwa tidak semua grid memiliki seluruh variabel. Hanya grid tertentu yang memiliki bobot variabel yang tinggi (Gambar 3). Hal ini diperkirakan karena kurangnya data pendukung seperti laporan masyarakat yang lebih akurat dan peta toponimi yang detail. Akan tetapi, dari hasil yang diperoleh dalam penelitian ini dapat ditunjukkan sensitivitas tiap-tiap grid di wilayah penelitian.

Analisis sensitivitas terhadap variabel pertama menunjukkan bahwa hanya sebagian kecil wilayah di Kecamatan Sarolangun yang pernah dilaporkan mengandung tinggalan arkeologi klasik (Gambar 4). Akan tetapi, hasil ini sangat mendukung pendapat dari Bronson (1977) mengenai pola penempatan pusat-pusat aktivitas masyarakat yang berada di pertemuan sungai-sungai utama (Bronson 1977). Hal ini karena sensitivitas tertinggi ditemukan di sekitar pertemuan antara Batang Asai dan Batang Tembesi.

Berdasarkan hasil validasi dengan cara pengamatan di lapangan terhadap lokasi yang dilaporkan mengandung tinggalan arkeologi di Kecamatan Sarolangun. Di situs-situs tersebut masih terdapat beberapa fragmen bata berukuran besar yang tersebar di sekitar fondasi Surau Kampung Lubuk atau Langgar Jannatul Khoir. Beberapa anggota masyarakat yang diwawancarai memberikan informasi bahwa di sekitar Kampung Lubuk terdapat bekas bangunan candi yang saat ini lokasinya digunakan masyarakat sebagai tempat berdirinya langgar atau mushola. Lokasi lain yang dilaporkan berada di lahan makam yang disebut-sebut sebagai Makam Muara Sawah.

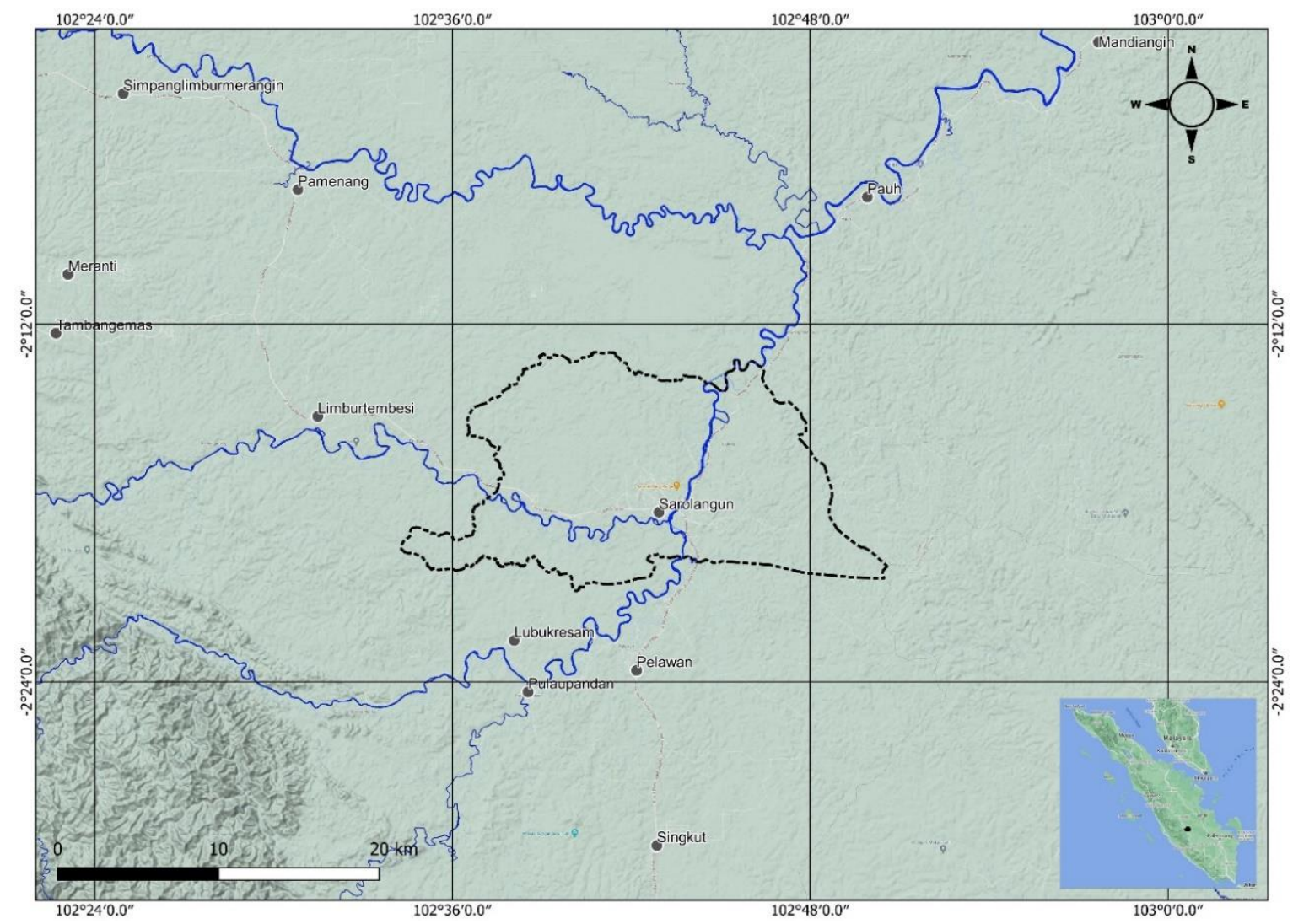

Sumber: Hasil penelitian 2019

Gambar 1 Lokasi Penelitian 


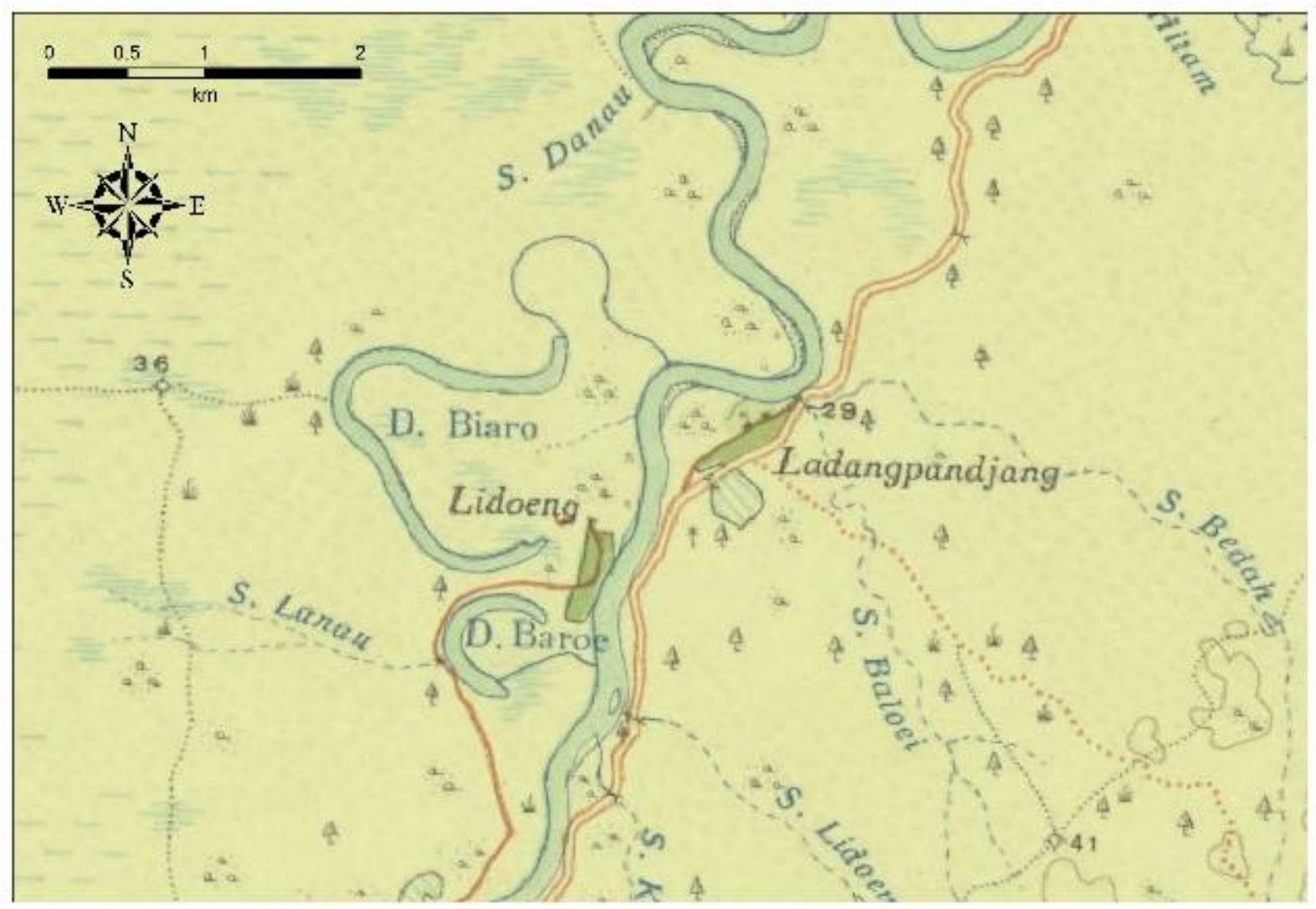

Sumber: Opgenomen door den Topografischen dienst in 1932-1934 Blad 24/XXIV

Gambar 2 Peta Sarolangun terbitan tahun 1935 menunjukkan adanya toponim Danau Biaro

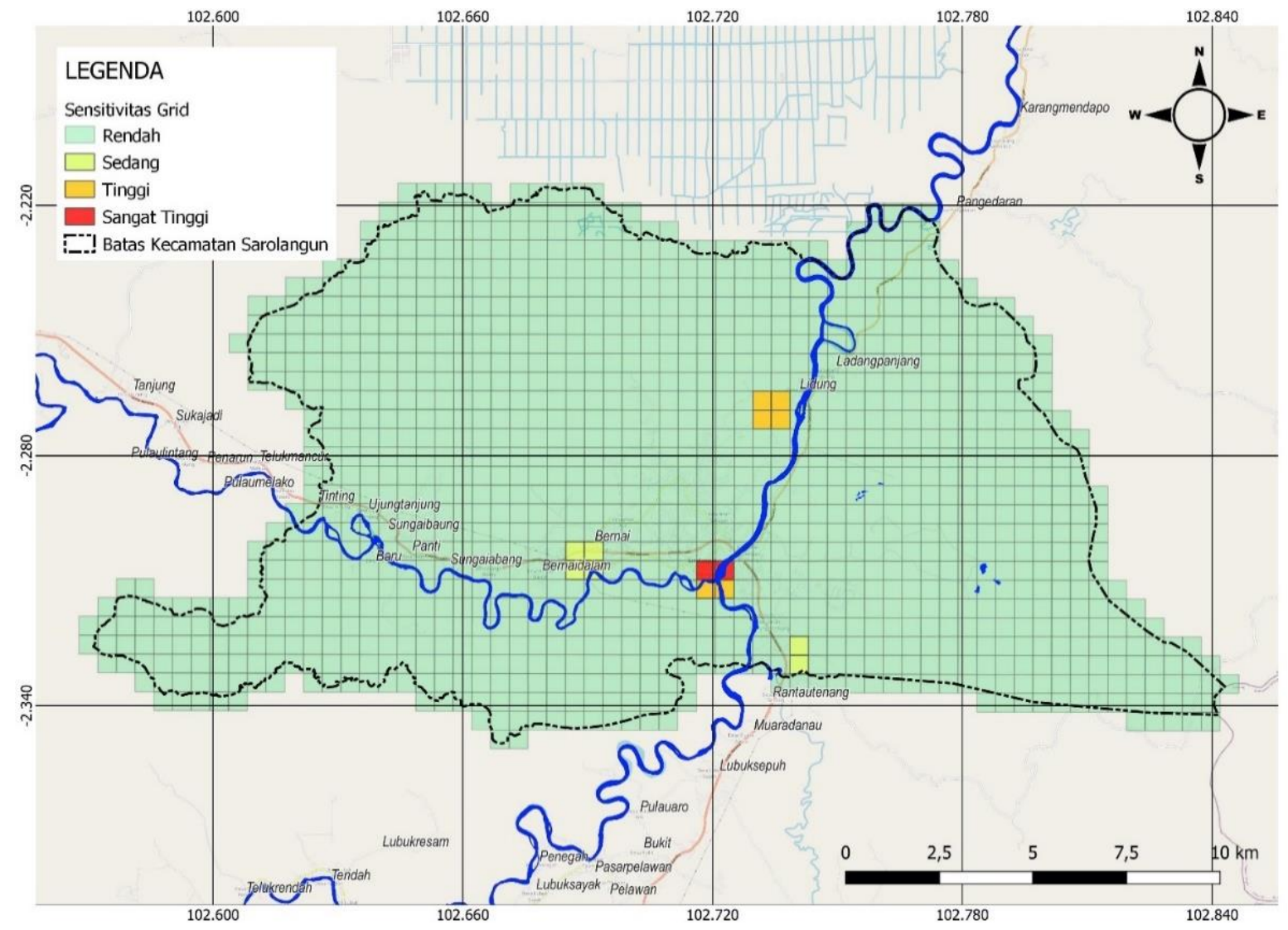

Sumber: Hasil Penelitian 2019

Gambar 3 Sensitivitas Grid 


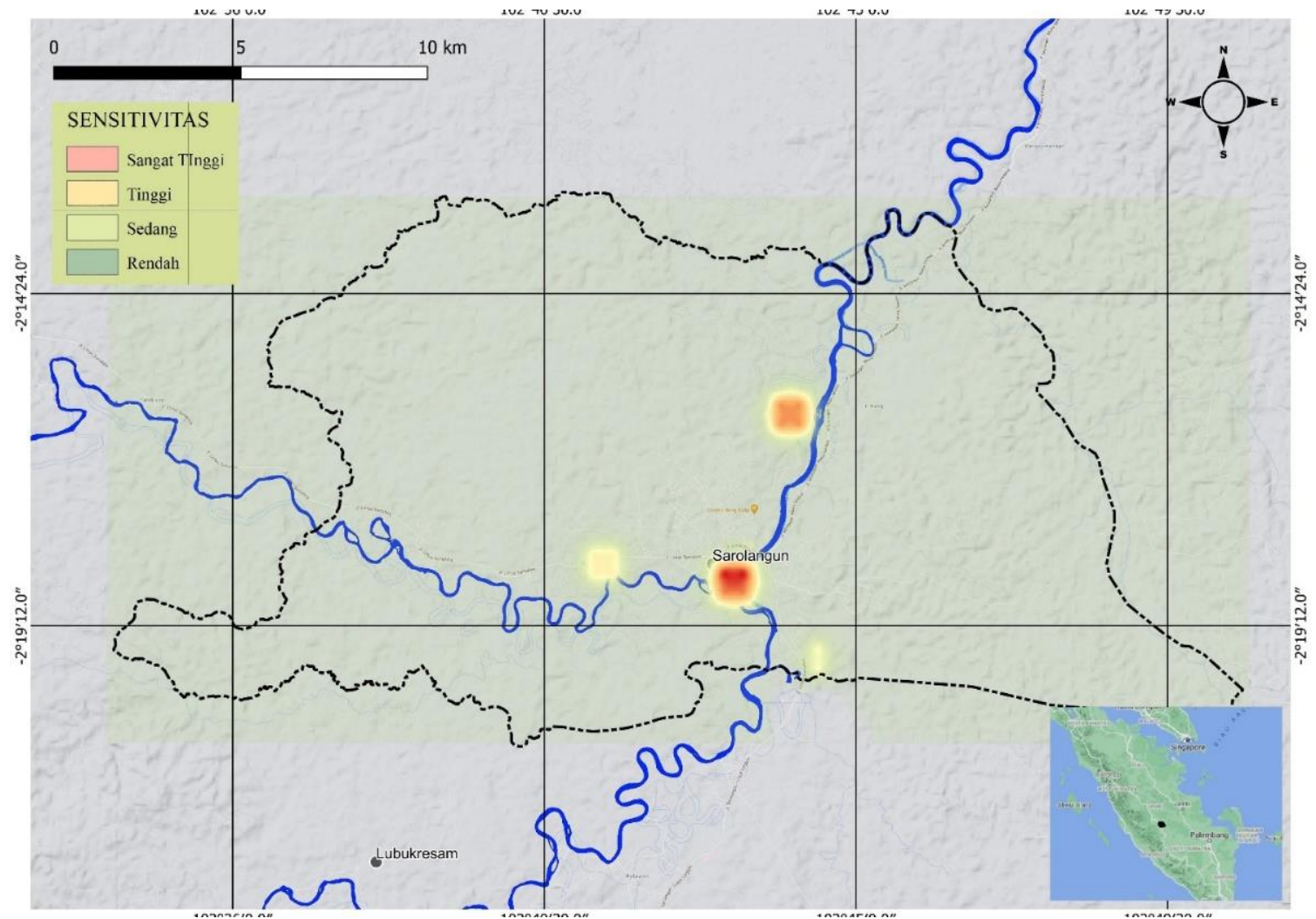

Sumber: Hasil penelitian 2019

Gambar 4 Sensitivitas Tinggalan Arkeologi Klasik di Kecamatan Sarolangun

Temuan bata pertama terletak di bagian utara surau tepatnya di bawah fondasi (tempat sampah) rumah panggung di samping surau (Gambar 5). Sekitar lima meter ke arah barat dari temuan bata pertama terdapat temuan empat fragmen tembikar yang diperkirakan merupakan bagian dari badan wadah (Gambar 6). Temuan bata kedua terletak di bagian barat laut surau atau tepatnya di sebelah selatan tempat imam (Gambar 7). Di lokasi ini juga ditemukan fragmen keramik yang berdasarkan warna dan bahannya diperkirakan dari masa Dinasti Sung (Gambar 8). Semua temuan permukaan yang berhasil diamati merupakan temuan lepas. Menurut informasi dari narasumber terdapat struktur bata yang masih tersusun di bawah fondasi langgar, terlihat ketika proses pembuatan fondasi.

Berdasarkan informasi dari narasumber selain di sekitar surau, temuan bata serupa juga ditemukan di Pemakaman Muara Sawah. Hasil pengamatan terhadap temuan permukaan menunjukkan keberadaan sebaran bata yang digunakan sebagai batas makam dan penggunaan batu sungkai (fosil kayu) sebagai penanda nisan (Gambar 9). Jenis dan ukuran bata yang ditemukan di Pemakaman Muara Sawah serupa dengan yang ada di Surau. Temuan bata di Pemakaman Muara Sawah berjumlah lebih banyak dan beberapa di antaranya merupakan bata kuncian (Gambar 10). Berkenaan dengan penggunaan batu sungkai (fosil kayu) sebagai nisan juga dapat ditemukan pada makam tokoh-tokoh penguasa atau orang-orang yang berjasa pada masa lalu, misalnya makam Bujang Kurap yang berada di Bukit Gunung Kembang (Gambar 11). Keberadaan batu sungkai (fosil kayu) memang umum ditemukan di sepanjang Sungai Batang Asai (Gambar 12).

Karakteristik tinggalan arkeologi yang ditemukan dalam proses validasi menunjukkan adanya keberlanjutan pemanfaatan wilayah dari periode klasik ke periode Islam. Sebaran bata yang ada di wilayah ini patut diduga kuat merupakan bagian dari komponen bangunan suci pada masa klasik. Bata yang dijumpai di Muara Sawah dan Kampung Lubuk memiliki ukuran yang mirip dengan bata dari Candi Solok Sipin. Dimensinya rata-rata lebih besar jika dibandingkan dengan bata dari Kompleks Percandian Muarajambi. Selain itu, temuan keramik Cina dari masa Dinasti Sung bersama dengan bata ini juga memperkuat dugaan bahwa pernah terdapat aktivitas manusia pada kurun yang sama dengan situs klasik lain di DAS Batanghari.

Perihal temuan arca yang pernah tercatat dalam laporan Belanda, arca Ganesha masih dapat ditemukan di Museum Sultan Mahmud Badaruddin II, tetapi dengan keterangan arca dari Surulangun, Musi Rawas, 
Sumatra Selatan (Museum Sultan Mahmud Badaruddin II 1984). Apabila dibandingkan dengan keterangan dari Bambang Budi Utomo (2016), arca yang sama memiliki keterangan berasal dari Desa Sarolangun, Kecamatan Sarolangun. Arca kedua yang disebutkan hilang dalam laporan Belanda sampai sekarang belum dapat ditelusuri.

Pemanfaatan batu sungkai sebagai penanda makam atau tempat yang dikeramatkan di Sarolangun sampai saat ini tidak dapat ditelusuri dari berbagai literatur. Batu sungkai sendiri merupakan fosil kayu yang sangat jarang dijumpai di Indonesia. Salah satu daerah yang menjadi penghasil fosil kayu sungkai ini adalah di daerah Merangin, Jambi (Andreani dan Prasetya 2019). Fenomena pemanfaatan batu sungkai sebagai penanda makam tentu saja memiliki keterkaitan dengan masuknya agama Islam ke wilayah pedalaman Jambi. Masuknya Islam ke wilayah ini diperkirakan bersamaan dengan maraknya migrasi masyarakat Minangkabau dari Pagaruyung untuk mencari emas di wilayah Merangin dan Sarolangun (Andaya 1993; Azmi 2018). Para pendatang tersebut pastinya memberikan pengaruh yang kuat terhadap komunitas masyarakat yang telah ada sebelumnya sejak periode klasik, baik dari segi pemilihan lokasi tempat tinggal maupun pusat-pusat interaksi sosial, religi, dan kegiatan perekonomian.

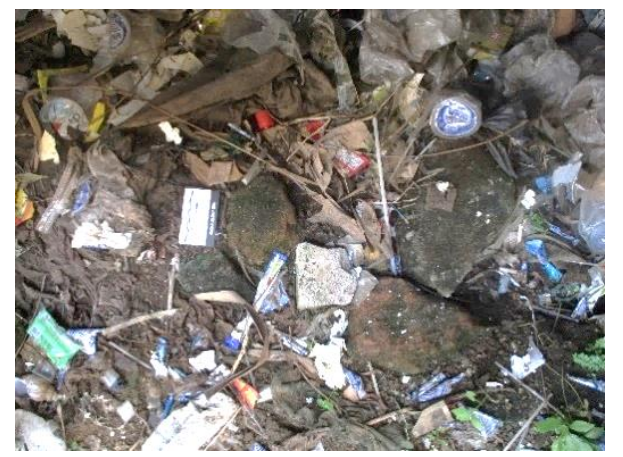

Sumber: Dok. Nainunis Aulia Izza

Gambar 5 Fragmen bata di utara Surau Kampung Lubuk, di kolong Rumah Panggung

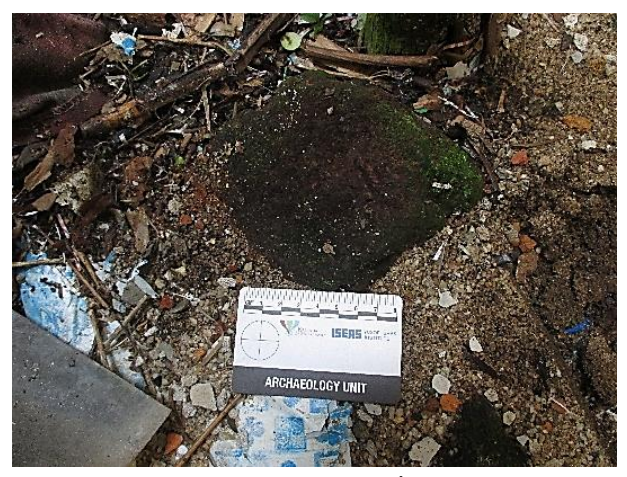

Sumber: Dok. Nainunis Aulia Izza

Gambar 7 Fragmen Bata di Sebelah Tempat Imam

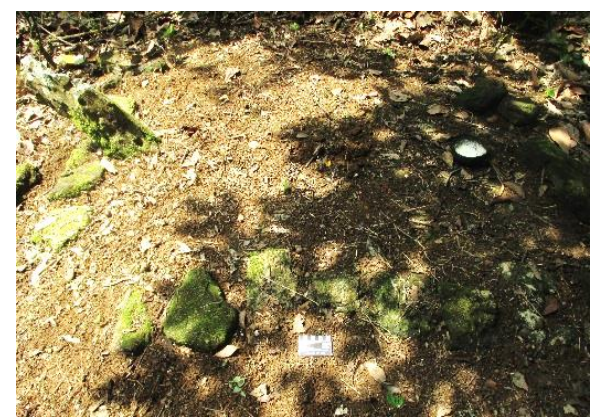

Sumber: Dok. Nainunis Aulia Izza

Gambar 9 Bata Candi dan Batu Sungkai di Pemakaman Muara Sawah

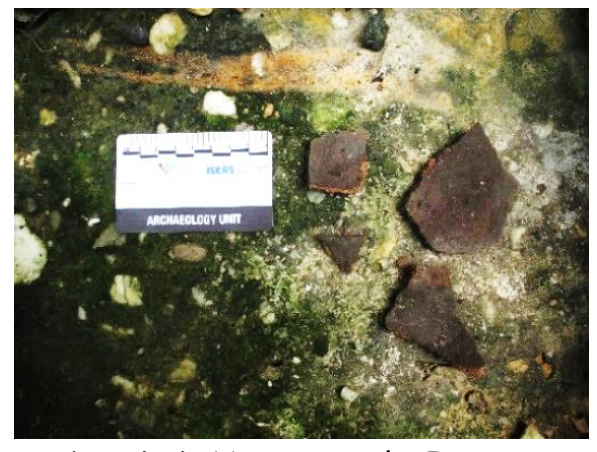

Sumber: Dok. Nainunis Aulia Izza

Gambar 6 Fragmen Tembikar di Utara Surau Kampung Lubuk

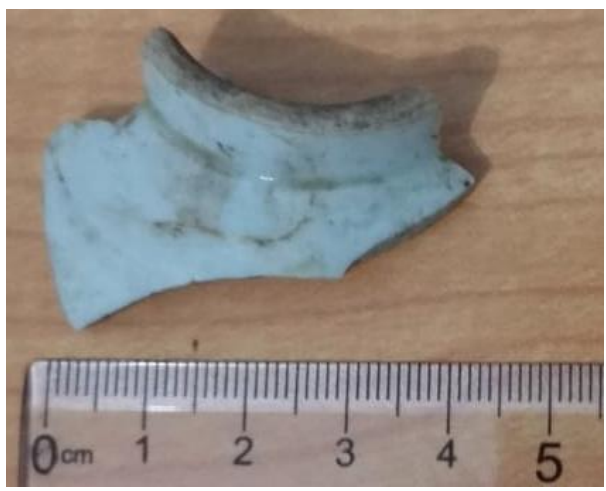

Sumber: Dok. Nainunis Aulia Izza

Gambar 8 Fragmen Keramik di Sebelah Tempat Imam

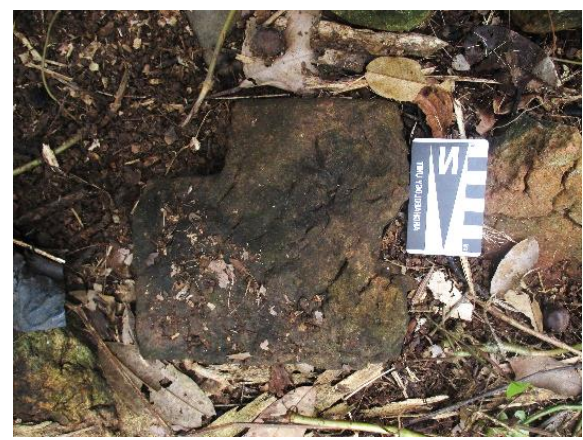

Sumber: Dok. Nainunis Aulia Izza

Gambar 10 Bata Kuncian di Pemakaman Muara Sawah 


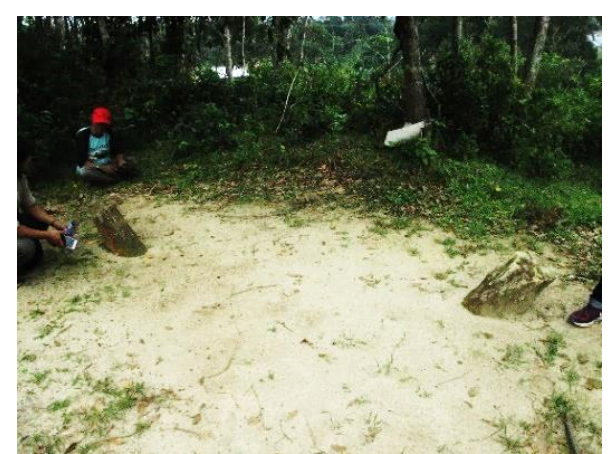

Sumber: Dok. Nainunis Aulia Izza

Gambar 11 Nisan Batu Sungkai (fosil kayu) di Makam Bujang Kurap, Gunung Kembang

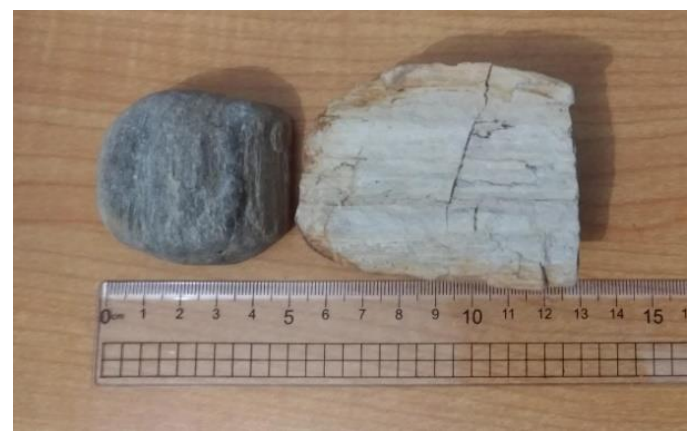

Sumber: Dok. Nainunis Aulia Izza

Gambar 12 Batu Sungkai dari tepi Sungai Batang Asai

\section{PENUTUP}

Penerapan pendekatan predictive modelling dalam upaya mencari lokasi-lokasi yang memiliki potensi tinggalan arkeologi sangat diperlukan, terutama dalam menentukan strategi ke depan, baik dalam bentuk riset lanjutan maupun arahan pelestariannya. Penelitian yang dilakukan ini menunjukkan bahwa analisis ini mampu menunjukkan area-area yang sekiranya patut diduga mengandung tinggalan arkeologi. Penentuan variabel yang sederhana sebagaimana dilakukan dalam penelitian ini sudah mampu menghasilkan beberapa lokasi yang dapat dianggap memiliki potensi tinggalan dari periode klasik. Apabila variabel ini kemudian nanti dikembangkan dan diterapkan menggunakan model pembobotan yang lebih kompleks pasti akan mampu menghasilkan peta sensitivitas yang lebih matang.

Kecamatan Sarolangun sebagai salah satu wilayah di DAS Batanghari ternyata menyimpan potensi tinggalan arkeologi klasik yang tidak kalah penting dengan situs-situs lain, seperti Muarajambi dan Dharmasraya. Kedudukannya secara geografis terletak di wilayah yang diduga kuat berkaitan dengan prasasti Karang Berahi, Candi Tingkip, dan Candi Lesung Batu di wilayah Musi Rawas. Wilayah-wilayah ini masih sangat jarang diteliti, apalagi jika dikaitkan dengan peradaban agama Hindu di wilayah DAS Batanghari. Selama ini DAS Batanghari diduga kuat menjadi nadi penyebaran Buddhisme di Sumatra karena tinggalan arkeologinya lebih banyak yang bernuansa agama Buddha. Adanya temuan yang bernuansa Hindu, tentu akan menjadi pembaruan dalam historiografinya, terlebih lagi jika didukung dengan situs pemukiman yang lebih kompleks.

Dalam melanjutkan penelitian ini ke tahap yang lebih detail diperlukan validasi yang mendalam terhadap metode yang sudah dilakukan. Validasi yang dimaksud adalah memetakan ulang sensitivitas area berdasarkan variabel dan pembobotan yang lebih kompleks. Setelah itu perlu juga dilakukan validasi di lapangan dengan survei detail, baik survei permukaan maupun ekskavasi yang terkontrol dengan baik.

\section{UCAPAN TERIMA KASIH}

Ucapan terima kasih penulis ucapkan, pertama kepada Lembaga Penelitian dan Pengabdian Masyarakat (LPPM) Universitas Jambi yang telah memberikan dana hibah penelitian tahun 2020. Selanjutnya terima kasih diucapkan kepada Fakultas IImu Budaya, Fakultas Keguruan dan IImu Pendidikan, Balai Arkeologi Sumatra Selatan, Balai Pelestarian Cagar Budaya Jambi, serta Dinas Pendidikan dan Kebudayaan Kabupaten Sarolangun atas fasilitasi persuratan dan perizinan sehingga penelitian ini dapat terlaksana. Terima kasih penulis ucapkan kepada seluruh pihak yang telah membantu secara langsung maupun tidak langsung demi terlaksananya penelitian ini. 


\section{DAFTAR PUSTAKA}

Adam, T. 1921. Oudheden te Djambi I. Weltevreden.

Adam, T. 1922. Oudheden te Djambi II. Weltevreden.

Adi, Ari Mukti Wardoyo. 2012. "Distribusi Situs Klasik di Wilayah Barat Gunung Merbabu: Kajian Analisis Lokasional." Universitas Gadjah Mada.

Adi, Ari Mukti Wardoyo. 2016. "Penerapan Analisis Predictive Modelling dalam Rangka Pelindungan Tinggalan Arkeologi Klasik di Kabupaten Magelang." Universitas Gadjah Mada.

Ahimsa-Putra, Heddy Shri. 1995. "Arkeologi Permukiman: Titik Strategis dan Beberapa Paradigma." HIm. 15 dalam Manusia Dalam Ruang: Studi Kawasan Dalam Arkeologi. Berkala Arkeologi.

Andaya, Barbara Watson. 1993. To Live as Brothers: Southeast Sumatra in the Seventeenth and Eighteenth Centuries. Honolulu: University of Hawai'i Press.

Andreani, Aninda Putri dan Rahmawan Dwi Prasetya. 2019. "Petrified Wood: Karakteristik dan Aplikasinya dalam Bidang Desain Produk." Jurnal Itenas Rekarupa 2(5):124-35.

Azmi, Ulul. 2018. "Konflik Penambangan Emas di Kecamatan Limun Kabupaten Sarolangun." Istoria: Jurnal IImiah Pendidikan Sejarah Universitas Batanghari 2(1):48-62.

Borrough, Peter A. dan Rachael A. McDonnell. 1998. Principles of Geographical Information Systems. Oxford: Oxford University Press.

Brandt, Roel, Bert J. Groenewoudt, dan Kenneth L. Kvamme. 1992. "An Experiment in Archaeological Site Location: Modelling in the Netherlands Using GIS Techniques." World Archaeology 24(2):268-82.

Bronson, Bennet. 1977. "Exchange at the Upstream and Downstream Ends: Notes towards a Functional Model of the Coastal State in Souteast Asia." Hal. 39-52 in Economic Exchage and Social Interaction in Southeast Asia: Perspective from Prehistory, History and Ethnography, diedit oleh K. L. Huterrer. Michigan: University of Michigan.

Coedes, George. 2010. Asia Tenggara Masa Hindu-Buddha. KPG (Kepustakaan Populer Gramedia).

Conolly, James dan Mark Lake. 2006. Geographical Information Systems in Archaeology. Cambridge: Cambridge University Press.

Degroot, Véronique. 2009. Candi Space and Landscape: A Study on the Distribution, Orientation and Spatial Organization of Central Javanese Temple Remains. Leiden: Leiden University.

Ebert, James I. dan Timothy A. Kobler. 1988. "The Theoretical Basis of Archaeological Predictive Modeling and A Consideration of Appropriate Data Collection Methods." HIm. 97-172 dalam Quantifying the Present and Predicting the Past: Theory, Method, and Application of Archaeological Predictive Modeling, diedit oleh W. J. Judge dan L. Sebastian. Denver: U.S. Department of the Interior, Bureau of Land Management Service Center.

Esquire, John Anderson. 1826. Mission to the East Coast of Sumatra, in 1823, Under the Direction of the Government of Prince of Wales Island. Edinburgh \& London: William Blackwood \& T. Cadell.

Gibbon, Guy. 2007. "Archaeological Predictive Modeling: An Overview." Minnesota Department of Transportation (MnDOT).

Groeneveldt, Willem Pieter. 2018. Nusantara dalam Catatan Tionghoa. Depok: Komunitas Bambu.

Hadi, Bambang Syaeful. 2013. "Metode Interpolasi Spasial dalam Studi Geografi (Ulasan Singkat dan Contoh Aplikasinya)." Geomedia 11(2):231-40.

Hardiati, Endang Sri, Hasan Djafar, Soeroso, P. E. .. Ferdinandus, dan Titi Surti Nastiti. 2010. Sejarah Nasional Indonesia Jilid II: Zaman Kuno. Jakarta: Balai Pustaka.

Krivoruchko, Konstantin., Alexander Gribov, dan Eric Krause. 2011. "Multivariate Areal Interpolation for Continuous and Count Data." in Procedia Environmental Sciences Vol. 3. Philladelphia: Elsevier Ltd.

Kvamme, Kenneth L. 1983. A Manual for Predictive Site Location Model: Examples from the Grand Junction District, Colorado. Denver.

Kvamme, Kenneth L. 1990. "The Fundamental Principles and Practice of Predictive Archaeological Modeling." Hal. 257-95 in Mathematics and Information Science in Archaeology, A Flexible Framework: Studies in Modern Archaeology Vol 3, diedit oleh A. Voorips. Bonn: Holos Verlag.

Kvamme, Kenneth L. 1997. "Archaeological Spatial Analysis Using GIS: Methods and Issues." HIm. 45-58 
Identifikasi Potensi Tinggalan Arkeologi Klasik Di Kecamatan Sarolangun, Jambi: Pendekatan Predictive Modelling-Nainunis Aulia Izza, Ari Mukti Wardoyo Adi, dan Nugrahadi Mahanani (59-70)

Doi: $10.24832 / n w . v 15 i 1.445$

dalam Sistemi Informativi e Reti Geografiche in Archeologia, diedit oleh A. Gottarelli. Sienna: Universita Degli Studi di Sienna.

Mashadi, Illham dan Zuharnen. 2014. "Kajian Keterkaitan Toponim Terhadap Fenomena Geografis: Studi Kasus Toponim Desa di Sebagian Kabupaten Batang." Jurnal Bumi Indonesia 3(4).

Munandar, Agus Aris. 2016. "Toponimi dalam Kajian Arkeologi." HIm. 1-26 dalam Proceedings Seminar Nasional Toponimi, diedit oleh S. Munawarah. Jakarta: Universitas Indonesia.

Mundarjito. 1993. "Pertimbangan Ekologis Penempatan Situs Masa Hindu-Buda di Daerah Yogyakarta: Kajian Arkeologi-Ruang Skala Makro." Universitas Indonesia.

Museum Sultan Mahmud Badaruddin II. 1984. Dokumentasi Koleksi Museum Sultan Mahmud Badaruddin II. Revisi. Palembang: Museum Sultan Mahmud Badaruddin II.

Neeb, C. J. 1902. "Het Een en Ander Over Hindoe Oudheden in Het Djambische." Hal. 120-33 in Tijdschrift voor Indische Taal-, Land- en Volkenkunde, dl 45: Hindu antiquities in Djambi, Indonesia, diedit oleh J. Brandes. Batavia: Lange \& Co.

Nugroho, Antar. 2000. "Pola Sebaran Situs-situs Masa Klasik di Kulonprogo." Universitas Gadjah Mada.

Parker, S. C. 1985. "Predictive Modelling of Site Settlement Systems Using Multivariate Logsitics." Hal. 173207 in For Concordance in Archaeological Analysis: Bridging Data Structure, Quantitative Technique, and Theory, diedit oleh C. Carr. Kansas City: Westport.

Robinson, J. .. dan E. Zubrow. 1999. "Between Spaces: Interpolation in Archaeology." HIm. 65-83 dalam Geographical Information Systems and Landscape Archaeology, diedit oleh M. Gillings, D. Mattingly, dan J. van Dalen. Oxford: Oxford Book.

Schnitger, F. M. 1937. The Archaeology of Hindoo Sumatra. Leiden: E. J. Brill.

Soeroso. 1996. "Pola Sebaran Situs Bangunan Masa Hindu Buda Di Wilayah Sumatera Selatan." in Pertemuan IImiah Arkeologi VII Jilid 5. Jakarta: Proyek Penelitian Arkeologi.

Taim, Eka Asih P. 2010. "Simangambat, Candi Hindu di Sumatera Utara." Berkala Arkeologi Sangkhakala 13(25):32-41.

Tideman, J. 1938. Djambi, Bewerkt door J. Tideman, Met Medewerkin. Amsterdam: Bruk de Bussy.

Tim Penelitian Arkeologi Muara Jambi. 1986. Laporan Penelitian Arkeologi Muara Jambi 1984. Jakarta.

Tombrink, E. P. 1870. "Hindoe-monumenten in Bovenlanden van Palembang, als bron van geschiedkundig onderzoek." Tijdschrift v. Indische Taal-, Land- en Volkenkunde Bataviaasch Genootschap v. Kunsten en Wetenschappen 19:1-45.

Ullmann, L. 1850. "Hindoe-beelden in de binnenlanden van Palembang." HIm. 493-94 dalam Indisch Archief: Tijdschrift voor de Indiën. Batavia: Lange.

Utomo, Bambang Budi. 2016. Pengaruh Kebudayaan India dalam Bentuk Arca di Sumatra. Jakarta: Yayasan Pustaka Obor.

Verhagen, Jacobus Wilhelmus Hermanus Philippus. 2007. "Case Studies in Archaeological Predictive Modelling." Leiden University Press, Leiden.

Wescott, Konnie L. dan R. Joe Brandon. 2000. Practical Applications of GIS for Archaeologists: A Predictive Modelling Toolkit. London: Taylor \& Francis.

Westenenk, Louis Constant. 1922. "De Hindoe-oudheden in de Pasemah-Hoogvlakte (Residentie Palembang)." HIm. 31-37 dalam Oudheidkundig Verslag. Weltevreden: Albrecht en co./'s-Gravenhage.

Yuwono, J. Susetyo Edy. 2015. "GIS Application for Archaeological Predictive Modelling: The Case Studies in Fluvio Volcanic and Karstic Landscape in Yogyakarta and Surrounding Area, Indonesia." in ANGIS and CRMA Bangkok Meeting 2015. Bangkok: Princess Maha Chakri Sirindhorn Anthropology Centre. 